\title{
Peripheral blood and hemoglobin electrophoresis pattern in beta thalassemia major patients receiving repeated blood transfusion
}

\author{
Riadi Wirawan*, Santy Setiawan*, Djajadiman Gatot ${ }^{f}$
}

\begin{abstract}
Abstrak
Seratus lima belas penderita thalassemia beta mayor yang mendapatkan tranfusi rutin di Pusat Thalassemia Bagian Ilmu Kesehatan Anak, Fakultas Kedokteran, Universitas Indonesia - Rumah Sakit Umum Pusat Dr. Cipto Mangunkusumo dilakukan pemeriksaan hematologi. Didapatkan korelasi yang negatif antara besarnya limpa dengan parameter hematologi darah tepi. Hasil pemeriksaan parameter darah tepi cenderung menurun dengan membesarnya limpa dan kondisi tersebut akan membaik setelah splenektomi. Pada penelitian kami hipersplenisme dimulai pada limpa $S(V-V I)$. Pemeriksaan elektroforesis hemoglobin didapatkan penebalan fraksi $\mathrm{HbF}$ dan 90 penderita tersebut menunjukkan pola yg normal. Oleh karena itu, untuk melakukan konfirmasi elektroforesis hemoglobin perlu dilakukan dengan pemeriksaan elektroforesis hemoglobin pada kedua orang tua atau pemeriksaan analisis genetik dengan teknik biomolekuler. (Med J Indones 2004; 13: 8-16)
\end{abstract}

\begin{abstract}
One hundred and fifteen beta thalassemia major outpatients attending the Thalassemia Center Department of Child Health, Medical School University of Indonesia Dr. Cipto Mangunkusumo General Hospital for routine blood transfusion and hematology examination, participated in this study. There was a negative correlation between the size of the spleen and the peripheral blood parameters. All peripheral blood parameters tend to decrease with the enlargement of the spleen, and the condition is reversed after splenectomy. We observed that hypersplenism starts when the spleen is as big as $S(V-V I)$. The hemoglobin electrophoresis pattern from beta thalassemia major patients receiving repeated blood transfusion did not show a dense HbF fraction, 90 patients showed a normal hemoglobin electrophoresis pattern. A hemoglobin analysis of both parents could be useful to confirm the diagnosis of beta thalassemia major for patients receiving repeated blood transfusion. In order to get a definite diagnosis, a genetic analysis by bio molecular technique is needed. (Med J Indones 2004; 13: 8-16)
\end{abstract}

Keywords: $\beta$ thalassemia major, hematology parameter, hemoglobin electrophoresis

Thalassemia belongs to a group of disorders in hemoglobin synthesis, which is autosomal recessively inherited from one or both parents. The disease is characterized by the absence or reduced synthesis of one or more globin chains. The main symptoms of thalassemia are caused by a discrepancy in globin chains. Abnormal hemoglobin synthesis belongs to a group of disorders called hemoglobinopathy. Another disorder included in this group of disorders is the

\footnotetext{
* Department of Clinical Pathology, Faculty of Medicine, University of Indonesia/Dr. Cipto Mangunkusumo General Hospital, Jakarta, Indonesia

${ }^{f}$ Hematology Subdivision, Department of Child Health, Faculty of Medicine, University of Indonesia/Dr. Cipto Mangunkusumo General Hospital, Jakarta, Indonesia
}

"variant hemoglobin" which is a disorder in the amino acid sequence of the globin chain. ${ }^{1,2}$

Beta thalassemia is caused by absent or reduced synthesis of the beta globin chain, due to a mutation in the beta globin gene located in chromosome 11. If this happens to both beta globin genes then it is called homozygous beta thalassemia and the clinical form is called beta thalassemia major. Geographically, beta thalassemia can be found in the Mediterranean, Middle East, Africa, India, Myanmar, South East Asia including Southern China, Malaysia, and Indonesia. ${ }^{1,2}$

The main symptom of beta thalassemia major is severe anemia due to ineffective erythropoeisis, haemolysis and hypersplenism. Intramedular erythrocyte precursors destruction instigates a decrease in erythrocyte release into the blood stream. Hemolytic activity in the 
reticulo-endothelial systems (RES) increases due to the destruction of inclusion bodies containing mature erythrocytes, leading to hyperplasia of the RES, erythroid system, and extramedular hemopoeisis. Extramedular hemopoeisis occurs in the liver and spleen, initiating hepatomegaly and splenomegaly. Splenomegaly is aggravated by increased function of the spleen to destruct inclusion bodies containing mature erythrocytes. Splenomegaly widens the spleen's pulpae and increases blood cell pooling which eventually decreases blood cell in the circulation. The transit time for blood cell in the pulpae increases and also the phagocytic process, ending up in hypersplenism, which aggravates the anemia and initiates leukopenia and/or thrombocytopenia.,

Beta thalassemia major patients need adequate and regular blood transfusions since their first year of life to survive and to prevent physical and mental defect. One of the complications which results from regular and repeated blood transfusions is hemochromatosis. To prevent iron accumulation in the body, ironchelating agents are usually given to these patients. ${ }^{1-6}$

The aims of this study are; first, to get a general description of the peripheral blood in beta thalassemia major patients receiving repeated blood transfusions. We would like to found out whether the peripheral blood description in these patients was altered by the transfusions. The peripheral blood parameters measured were haemoglobin, hematocrit, RBC, mean corpuscular volume (MCV), mean corpuscular hemoglobin $(\mathrm{MCH})$, mean corpuscular hemoglobin concentration (MCHC), WBC, and platelet count. Second, to know the hemoglobin electrophoresis pattern in these patients. Third, to determine the onset of hypersplenism in beta thalassemia major patients, as these patients has had anemia since early life. Fourth, to analyze the relationship between enlarged spleen and peripheral blood parameters.

\section{METHODS}

One hundred and fifteen beta thalassemia major patients scheduled for blood transfusion at the Thalassemia Center Department of Paediatrics, Medical School University of Indonesia - Cipto Mangunkusumo General Hospital with the following inclusion criteria were included in this study:

1. Diagnosed as beta thalassemia major according to their medical record.

2. Aged between 9 to 23 .
3. Had received regular blood transfusion for at least 1 year.

This study passed the ethical evaluation by the Committee of Ethics, School of Medicine University of Indonesia. We excluded patients who refused to participate in this study.

Two $\mathrm{mL}$ of blood was drawn from all participants prior to the transfusion by venipuncture from the cubital vein with a sterile syringe. One drop of blood was used to make a fresh blood smear; the remaining blood sample was kept in a vacuette containing tripotassium ethylene diamine tetra acetate $\left(\mathrm{K}_{3} \mathrm{EDTA}\right)$ for hematology examinations. After assessing the following parameters; hemoglobin, hematocrit, RBC, $\mathrm{MCV}, \mathrm{MCH}, \mathrm{MCHC}, \mathrm{WBC}$, and platelet count, the remaining EDTA blood was centrifuged at $3000 \mathrm{rpm}$ for 10 minutes. Packed red cells were used for hemoglobin electrophoresis.

From 162 subjects visiting the Thalassemia Center Department of Paediatrics, University of Indonesia Medical School Cipto Mangunkusumo General Hospital, 115 subjects met the required criteria for this study. A physical examination to asses the spleen was done.

Before laboratory examination was performed, within day and between day precision and an accuracy tests were done for all laboratory instruments used in this study. The instrument used in this study is the Cell-Dyn 1700, and the control solution Cell-Dyn 16 Tri-Level. ${ }^{8}$

Hemoglobin electrophoresis was done with an electrophoresis instrument from Helena Laboratories, alkaline buffer ( $\mathrm{pH} 8.2$ - 8.6), using hemolyzed EDTA blood, with cellulose acetate as media. ${ }^{9}$ Normal adult blood was used as control for electrophoresis. Blood smears were stained with Wright and a correction for WBC was done. ${ }^{10,11}$

\section{Definitions}

Beta thalassemia major is diagnosed if the earliest hemoglobin electrophoresis recorded in the medical record has a 10-90\% $\mathrm{HbF}$ concentration, accompanied by splenomegaly or a history of splenectomy, giving a distinct pattern on $\mathrm{Hb}$ electrophoresis, $\mathrm{HbA}, \mathrm{HbA}_{2}$, with or without $\mathrm{HbF}$, and no abnormal $\mathrm{Hb}$ fraction.

Hypersplenism is defined as having splenomegaly accompanied with pancytopenia. 


\section{Data analysis}

This study is a cross sectional study, we evaluated the precision of test results by measuring its coefficient of variation $(\mathrm{CV})$ and the accuracy by its deviation from the target value (d). We did an analysis of variance (ANOVA) to search for correlations between splenomegaly and hematology parameters. We did a descriptive report on hematology parameters and hemoglobin electrophoresis pattern found in this study.

\section{RESULTS}

Within run and between day precision and accuracy of hematology parameters tested on the Cell-Dyn 1700 using Cell-Dyn 16 Tri-Level, are listed in table 1.

Information regarding subjects participating this study is listed in table 2 .

The range of hematology parameters from 115 subjects was as follows: hemoglobin ( $\mathrm{Hb}$ ) 4.2 - 9.6 $\mathrm{g} / \mathrm{dL}$, hematocrit (Ht) $11-28 \%$, erythrocyte count
(RBC) $1.54-3.95$ million $/ \mu \mathrm{L}$, leukocyte count (WBC) $2.000-21.400 / \mu \mathrm{L}$, and platelet count 20.000

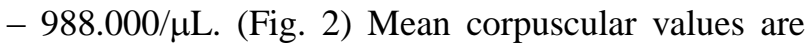
shown in fig. 3, MCV ranging from $62 \mathrm{fL}-88 \mathrm{fL}$, MCH $19-33 \mathrm{pg}$, and MCHC $26-39 \mathrm{~g} / \mathrm{dL}$.

Subjects with spleen enlargement from S (I) to S (VII) and post splenectomy $\mathrm{S}(-)$ were sorted into 5 groups. Group S $(\mathrm{I}-\mathrm{II})=26$ subjects, group $\mathrm{S}(\mathrm{III}-\mathrm{IV})=39$ subjects, group $\mathrm{S}(\mathrm{V}-\mathrm{VI})=12$ subjects, group $\mathrm{S}(\mathrm{VII}$ $-\mathrm{VIII})=9$ subjects, and group $\mathrm{S}(-)=29$ subjects .

The ANOVA result for correlation between enlarged spleen and $\mathrm{Hb}$ concentration, $\mathrm{Ht}, \mathrm{RBC}, \mathrm{WBC}$, and platelet count were $\mathrm{p}=0.003 ; 0.000 ; 0.003 ; 0.000$; and 0.000 respectively, which means that there was a significant difference.

Figure 4 shows that the mean haemoglobin concentration, hematocrit, RBC, WBC, and platelet count inclined to decrease when the spleen is enlarged and are likely to reverse to normal after splenectomy. Leukopenia and thrombocytopenia is clearly observed in subjects with $\mathrm{S}(\mathrm{V}-\mathrm{VI})$ spleens.

Table 1. Within run and between day precision of Cell-Dyn 1700

\begin{tabular}{|c|c|c|c|c|c|c|c|c|c|}
\hline \multicolumn{2}{|c|}{ Parameter } & $\mathrm{Hb}$ & Ht & $\mathrm{E}$ & $\mathrm{MCV}$ & $\mathrm{MCH}$ & $\mathrm{MCHC}$ & $\mathrm{L}$ & Plt \\
\hline \multicolumn{10}{|c|}{ Precision } \\
\hline \multicolumn{2}{|c|}{ WR: CV (\%) } & 0.34 & 1.65 & 1.47 & 0.26 & 1.68 & 1.86 & 0.68 & 2.20 \\
\hline \multicolumn{2}{|c|}{ BD: CV $(\%)$} & 2.07 & 1.76 & 1.51 & 0.85 & 2.78 & 2.60 & 2.44 & 5.13 \\
\hline \multicolumn{10}{|c|}{ Accuracy } \\
\hline WR & \multicolumn{3}{|c|}{$=$ within-run } & $\mathrm{E}$ & \multicolumn{5}{|l|}{$=\mathrm{RBC}$} \\
\hline $\mathrm{BD}$ & \multicolumn{3}{|c|}{$=$ between-day } & $\mathrm{L}$ & \multicolumn{5}{|c|}{$=\mathrm{WBC}$} \\
\hline $\mathrm{CV}$ & \multicolumn{3}{|c|}{$=$ coefficient of variation } & Plt & \multicolumn{5}{|c|}{$=$ platelet count } \\
\hline $\mathrm{d}$ & \multicolumn{3}{|c|}{$=$ deviation } & $\mathrm{MCV}$ & \multicolumn{5}{|c|}{$=$ mean corpuscular volume } \\
\hline $\mathrm{Hb}$ & \multicolumn{3}{|c|}{$=$ hemoglobin concentration } & $\mathrm{MCH}$ & \multicolumn{5}{|c|}{$=$ mean corpuscular hemoglobin } \\
\hline $\mathrm{Ht}$ & \multicolumn{3}{|c|}{$=$ hematocrit } & $\mathrm{MCHC}$ & \multicolumn{5}{|c|}{$=$ mean corpuscular hemoglobin concentration } \\
\hline
\end{tabular}

Table 2. List of participants

\begin{tabular}{lcc}
\hline \multicolumn{3}{c}{ Total 115 subjects } \\
\hline Gender & Male & Female \\
\hline *Number of subjects & $55(47.8 \%)$ & $60(52.2 \%)$ \\
*Age range & $9 \mathrm{y} .1 \mathrm{mo} .-22 \mathrm{y} .5 \mathrm{mo}$. & 9 y. 1 mo. $-22 \mathrm{y} .3 \mathrm{mo}$. \\
*First transfusion at age & $3 \mathrm{mo}-9 \mathrm{y}$. & $2 \mathrm{mo} .-6 \mathrm{y}$. \\
*Volume of blood received & $14.455-124.685 \mathrm{~mL}$ & $12.400-199.910 \mathrm{~mL}$ \\
*Dense HbF fraction (transfusion period) & 5 subjects $(9-17 \mathrm{y})$ & 20 subjects $(4-20 \mathrm{y})$ \\
\hline
\end{tabular}


Only $25(21,7 \%)$ out of $115(100 \%)$ beta thalassemia major patients, receiving regular packed red cells (PRC) transfusion once every 2 - 4 weeks, showed dense $\mathrm{HbF}$ fraction. Their ages ranged from 9 year and one month to 21 years old and had a period of blood transfusions ranging from $4-20$ years. The remaining $90(78.3 \%)$ subjects showed normal adult hemoglobin electrophoresis pattern with a slight $\mathrm{HbA}_{2}$ band, their ages ranging from 9 year and one month to 22 year and 5 months and had had blood transfusion for a period ranging from $3-21$ years. (Fig. 5 and Table 2)

Table 3. Comparison of hematology parameters CV (\%)

\begin{tabular}{lcccccccc}
\hline & $\mathrm{Hb}$ & $\mathrm{Ht}$ & $\mathrm{E}$ & $\mathrm{MCV}$ & $\mathrm{MCH}$ & $\mathrm{MCHC}$ & $\mathrm{L}$ & Plt \\
\hline WHO & 2 & $4-5$ & 2 & $4-5$ & $4-5$ & $4-5$ & 5 & $10-15$ \\
NCCLS & $<3$ & n.a. & $<3.7$ & $<3.3$ & n.a. & n.a. & $<12$ & $\leq 14.8$ \\
Manufacturer & $\leq 1.2$ & n.a. & $\leq 1.7$ & $\leq 1.5$ & n.a. & n.a. & $\leq 2.5$ & $\leq 6.0$ \\
Study & 0.34 & 1.65 & 1.47 & 0.26 & 1.68 & 1.86 & 0.68 & 2.20 \\
\hline
\end{tabular}

$\mathrm{CV}=$ coefficient of variation. $\mathrm{Hb}=$ hemoglobin concentration, $\mathrm{Ht}=$ hematocrit, $\mathrm{E}=\mathrm{RBC}, \mathrm{MCV}=$ mean corpuscular volume, $\mathrm{MCH}=$ mean corpuscular hemoglobin, $\mathrm{MCHC}=$ mean corpuscular hemoglobin concentration, $\mathrm{L}=\mathrm{WBC}$, Plt = platelet count, $\mathrm{WHO}=$ World Health Organization, NCCLS $=$ National Committee for Clinical Laboratory Standards, n.a. $=$ not available.

Table 4. Hemoglobin, leukocytes and platelets vs. spleen condition

\begin{tabular}{lllc}
\hline \multirow{2}{*}{ PARAMETER } & \multicolumn{2}{c}{ SPLEEN CONDITION } \\
\cline { 3 - 4 } & & \multicolumn{1}{c}{$\begin{array}{c}\text { Splenomegaly } \\
(\mathrm{n}=86)\end{array}$} & $\begin{array}{c}\text { Postsplenectomy } \\
(\mathrm{n}=29)\end{array}$ \\
\hline \multirow{2}{*}{ Hemoglobin concentration } & Anemia & $86(4.2-9.6 \mathrm{~g} / \mathrm{dL})$ & $29(4.9-8.1 \mathrm{~g} / \mathrm{dL})$ \\
WBC (range) & Leukopenia & $32(2.000-4.000 / \mu \mathrm{L})$ & 0 \\
& $\begin{array}{l}\text { Normal } \\
\text { Leukocytosis }\end{array}$ & $44(5.000-9.900 / \mu \mathrm{L})$ & $2(7.700-9.200 / \mu \mathrm{L})$ \\
& $10(10.300-16.500 / \mu \mathrm{L})$ & $27(10.200-21.400 / \mu \mathrm{L})$ \\
Platelet count (range) & Thrombocytopenia & $42(20.000-147.000 / \mu \mathrm{L})$ & 0 \\
& $\begin{array}{l}\text { Normal } \\
\text { Thrombocytosis }\end{array}$ & $40(152.000-396.000 / \mu \mathrm{L})$ & $5(153.000-376.000 / \mu \mathrm{L})$ \\
& $4(428.000-530.000 / \mu \mathrm{L})$ & $24(410.000-988.000 / \mu \mathrm{L})$ \\
\hline
\end{tabular}

Table 5. Mean and range of $\mathrm{Hb}$ concentration, $\mathrm{Ht}$, erythrocyte, leucocyteand platelet count vs. spleen enlargement in beta thalassemia major patients receiving repeated blood transfusion.

\begin{tabular}{|c|c|c|c|c|c|}
\hline $\begin{array}{l}\text { SPLEEN } \\
\text { ENLARGEMENT }\end{array}$ & $\begin{array}{c}\mathrm{Hb} \\
(\mathrm{g} / \mathrm{dL})\end{array}$ & $\begin{array}{l}\mathrm{Ht} \\
(\%)\end{array}$ & $\begin{array}{l}\text { Erythrocyte } \\
\text { (million } / \mu \mathrm{L} \text { ) }\end{array}$ & $\begin{array}{c}\text { Leukocytes* } \\
\text { (thousands } / \mu \mathrm{L} \text { ) }\end{array}$ & $\begin{array}{l}\text { Thrombocytes } \\
\text { (thousands } / \mu \mathrm{L} \text { ) }\end{array}$ \\
\hline $\begin{array}{l}\mathrm{S}(\mathrm{I}-\mathrm{II}) \\
\mathrm{n}=26\end{array}$ & $\begin{array}{c}7.3 \\
(5.4-9.6)\end{array}$ & $\begin{array}{c}22.6 \\
(16.6-28.0)\end{array}$ & $\begin{array}{c}3.0 \\
(2.22-3.95)\end{array}$ & $\begin{array}{c}8.0 \\
(4.1-16.5)\end{array}$ & $\begin{array}{c}238 \\
(20-530)\end{array}$ \\
\hline $\begin{array}{l}\mathrm{S}(\mathrm{III}-\mathrm{IV}) \\
\mathrm{n}=39\end{array}$ & $\begin{array}{c}6.8 \\
(4.3-8.0)\end{array}$ & $\begin{array}{c}20.2 \\
(11.6-26.3)\end{array}$ & $\begin{array}{c}2.66 \\
(1.62-3.48)\end{array}$ & $\begin{array}{c}6.7 \\
(2.5-14.0)\end{array}$ & $\begin{array}{c}176 \\
(58-461)\end{array}$ \\
\hline $\begin{array}{l}\mathrm{S}(\mathrm{V}-\mathrm{VI}) \\
\mathrm{n}=\mathbf{1 2}\end{array}$ & $\begin{array}{c}6.1 \\
(4.2-7.8)\end{array}$ & $\begin{array}{c}18.4 \\
(11.0-22.9)\end{array}$ & $\begin{array}{c}2.54 \\
(1.54-3.50)\end{array}$ & $\begin{array}{c}4.9 \\
(2.8-7.3)\end{array}$ & $\begin{array}{c}114 \\
(61-228)\end{array}$ \\
\hline $\begin{array}{l}\mathrm{S}(\mathrm{VII}-\mathrm{VIII}) \\
\mathrm{n}=9\end{array}$ & $\begin{array}{c}5.7 \\
(4.8-7.5)\end{array}$ & $\begin{array}{c}17.2 \\
(14.0-21.5)\end{array}$ & $\begin{array}{c}2.28 \\
(1.65-2.91)\end{array}$ & $\begin{array}{c}4.3 \\
(2.0-6.9)\end{array}$ & $\begin{array}{c}106 \\
(54-222)\end{array}$ \\
\hline $\begin{array}{l}\mathrm{S}(-) \\
\mathrm{n}=29\end{array}$ & $\begin{array}{c}7.1 \\
(4.9-8.1)\end{array}$ & $\begin{array}{c}22.0 \\
(15.7-25.6)\end{array}$ & $\begin{array}{c}2.84 \\
(2.03-3.82)\end{array}$ & $\begin{array}{c}14.0 \\
(7.7-21.4)\end{array}$ & $\begin{array}{c}554 \\
(153-988)\end{array}$ \\
\hline
\end{tabular}

$\mathrm{Hb}=$ hemoglobin concentration; $\mathrm{Ht}=$ hematocrit; Leukocytes* = corrected $\mathrm{WBC} ; \mathrm{S}=$ Schüffner 


\section{Procedures}

Blood drawn prior to transfusion

Beta thalassemia major patient

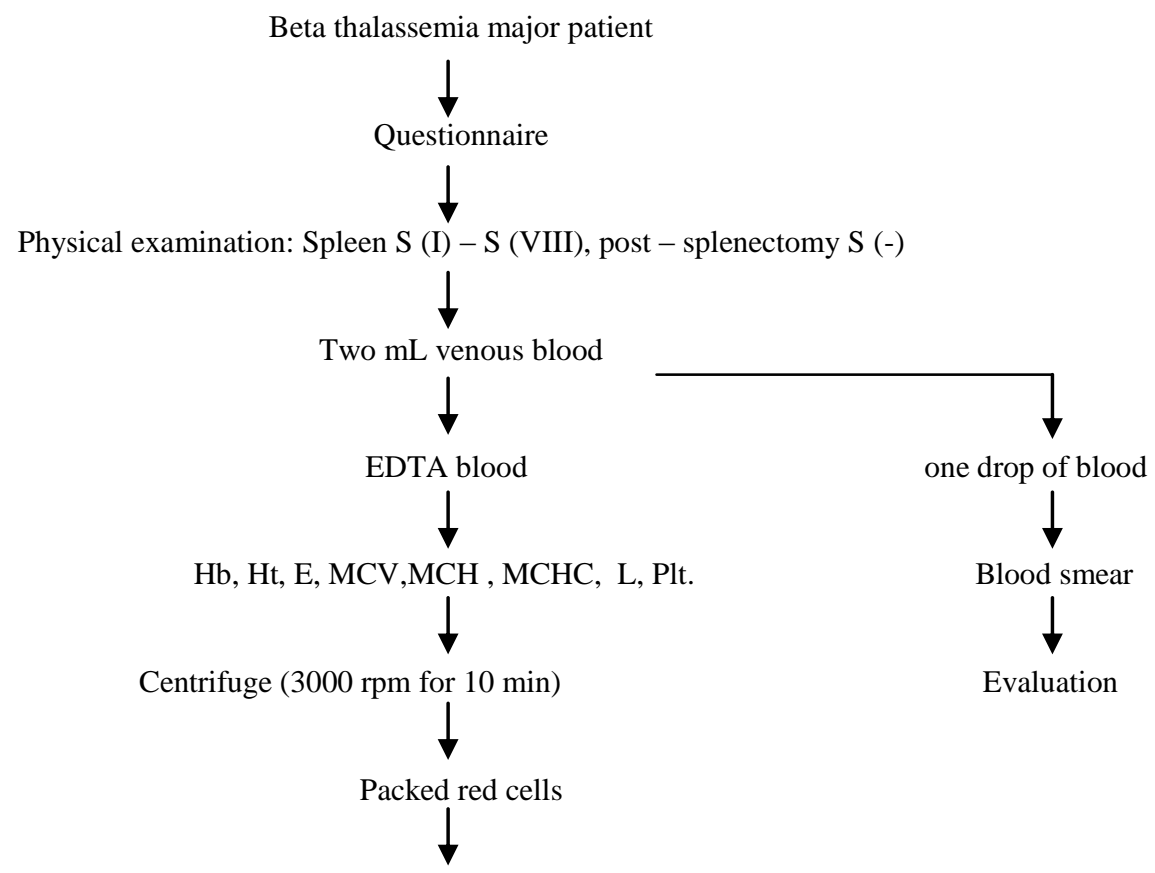

Hemoglobin electrophoresis

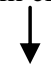

Hemoglobin fraction

$\mathrm{S}=$ Schüffner, EDTA = ethylene diamine tetra acetate, $\mathrm{Hb}=$ hemoglobin concentration, $\mathrm{Ht}=$ Hematocrit, $\mathrm{MCV}=$ mean corpuscular volume $\mathrm{E}=\mathrm{RBC}, \mathrm{MCHC}=$ mean corpuscular hemoglobin concentration, $\mathrm{MCH}=$ mean corpuscular hemoglobin, $\mathrm{L}=\mathrm{WBC}, \mathrm{Plt}=$ platelet count .

Figure 1. Flow chart of procedures

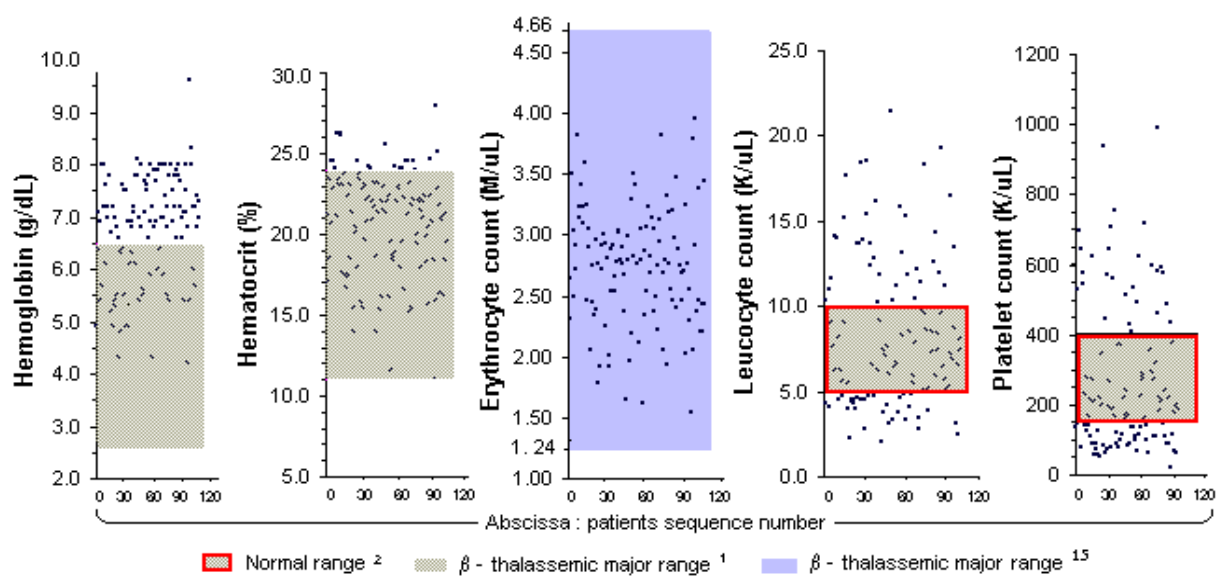

Figure 2. Hemoglobin, hematocrit, RBC, WBC, and platelet count from $\beta$ thalassemia major patients receiving repeated blood tranfusion 


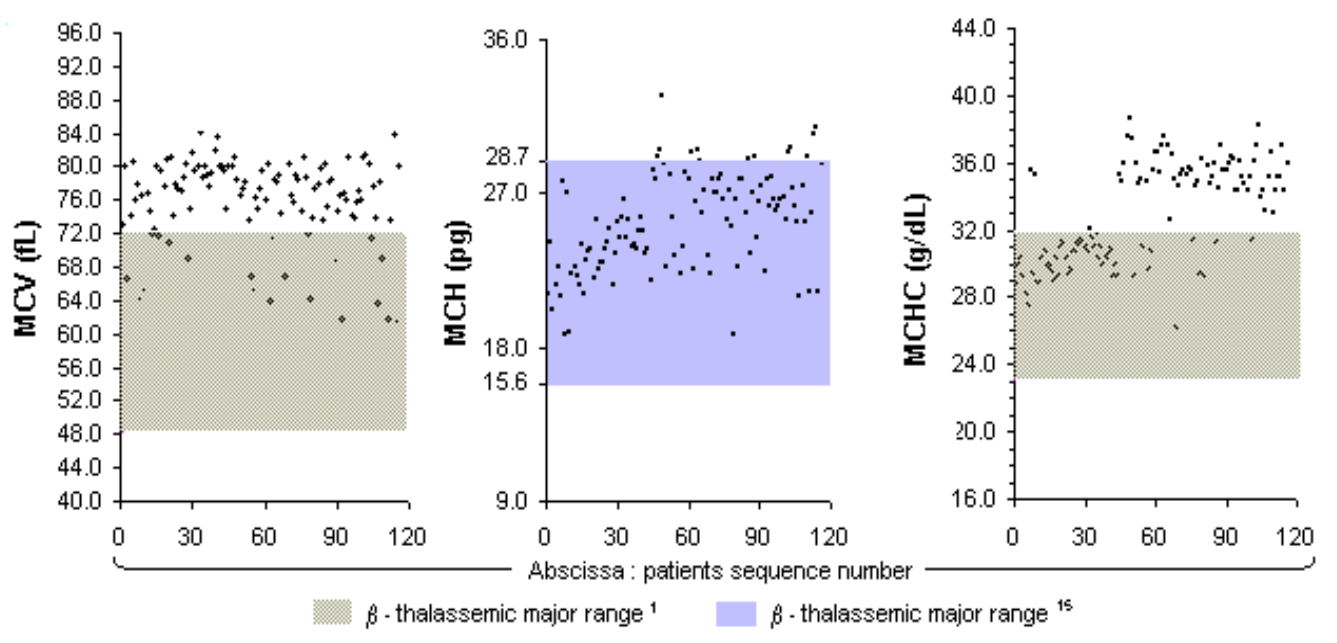

Figure 3. Mean corpuscular volume, MCH, MCHC from $\beta$ thalassemia major patients receiving repeated blood transfusion
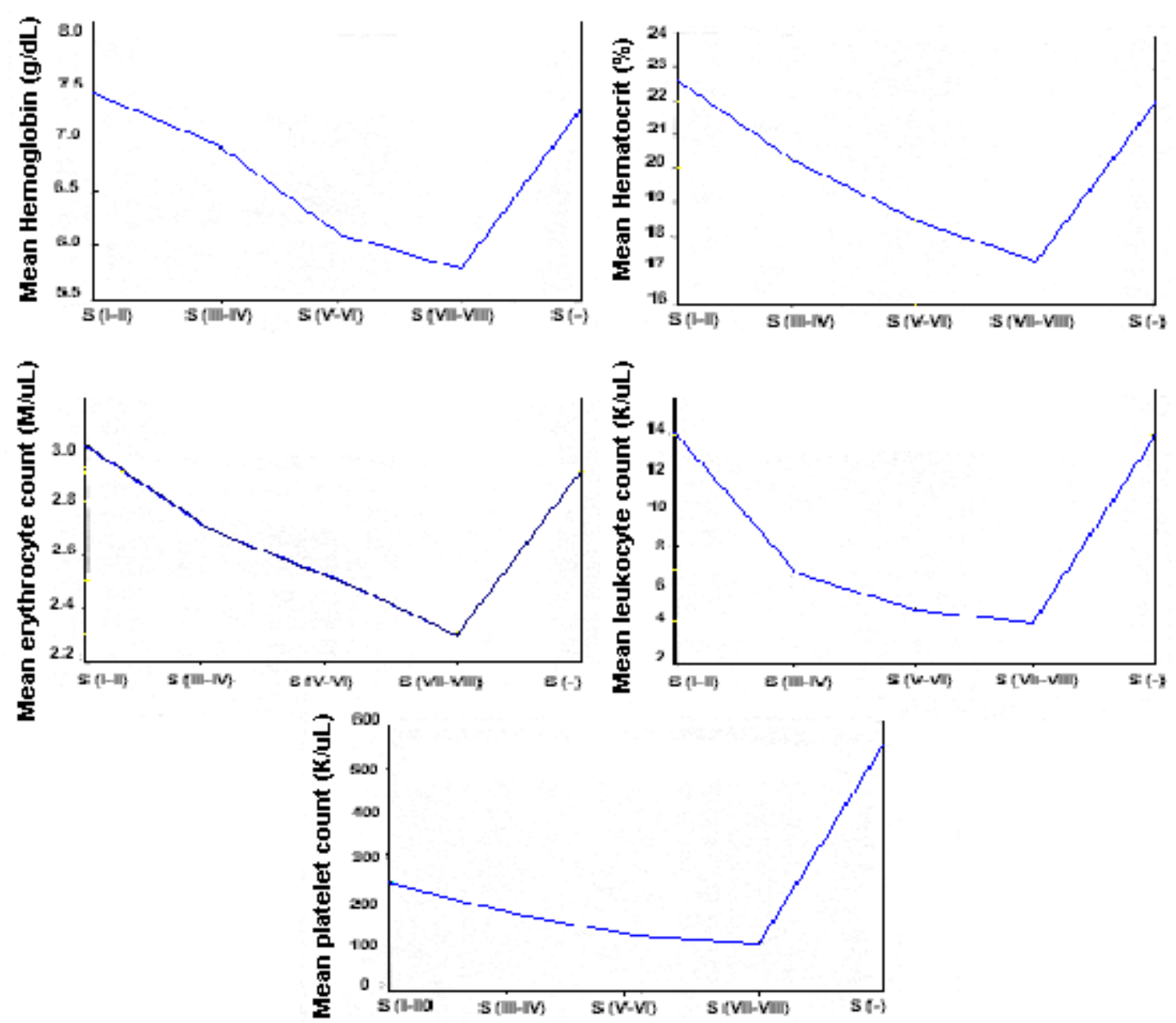

Figure 4. Changes in means from $\mathrm{Hb}, \mathrm{Ht}, \mathrm{RBC}, \mathrm{WBC}$, and platelet count against spleen (enlargement) condition 


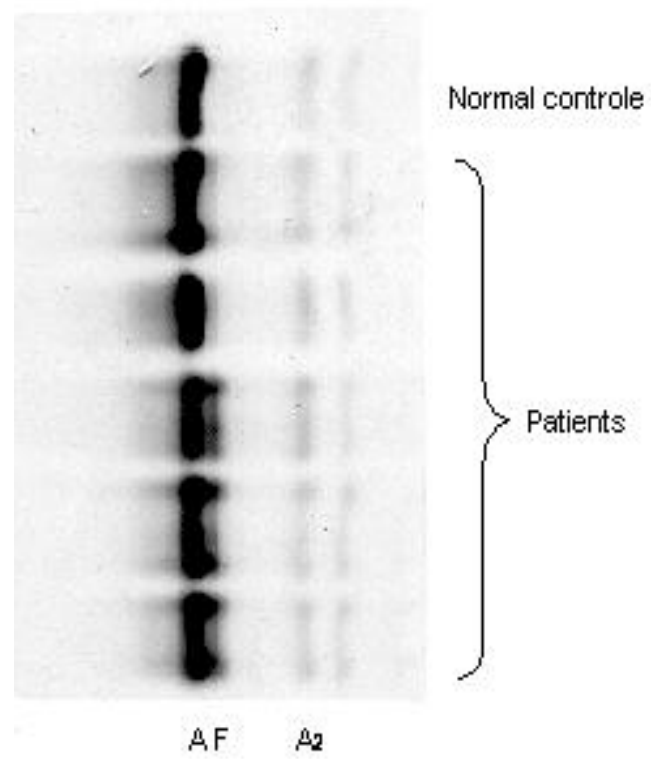

Fig. 5. Hemoglobin electrophoresis pattern

\section{DISCUSSION}

The precision performance of Cell-Dyn 1700 used in this study compared to WHO, ${ }^{12}$ NCCLS, ${ }^{13}$ and the manufacturer ${ }^{8}$ is listed in table 3 .

The accuracy performance of Cell-Dyn 1700 used in this study was within the \pm 2 SD range from the target value for each parameter. Minus zero point one percent for $\mathrm{Hb}, 0.31 \%$ for $\mathrm{Ht}, 0.47 \%$ for $\mathrm{MCV},-0.46$ $\%$ for $\mathrm{MCH},-0.93 \%$ for $\mathrm{MCHC},-0.09 \%$ for $\mathrm{RBC}$, $0.49 \%$ for $\mathrm{WBC}$, and $-2.68 \%$ for platelet count. The Cell-Dyn 1700 used in this study gave accurate and precise results.

Hematology parameters from beta thalassemia major patients were characteristic for anemia with hemoglobin, $2.5-6.5 \mathrm{~g} / \mathrm{dL}$, hematocrit, $11-24 \%$; MCV, $48-72 \mathrm{fL}$; and MCHC, $23-32 \mathrm{~g} / \mathrm{dL}$, while leukocyte and platelet count were in the normal range or slightly increased. Referring to a report by Lie-Injo the $\mathrm{RBC}$ and $\mathrm{MCH}$ were as low as $1.24-4.66$ million $/ \mu \mathrm{L}$ and $15.6-28.7 \mathrm{pg}$ respectively in beta thalassemia major patients. ${ }^{14}$

Pictures 2 and 3 describe the hematology parameters from beta thalassemia major patients who had repeated blood transfusion, the pattern differed from typical beta thalassemia major patient. According to Weatherall, ${ }^{15}$ the difference is caused by suppression of endogenic erythropoeisis in the bone marrow and the peripheral blood pattern is dominated by transfused blood.

WBC after correction for nucleated erythrocyte precursors (table 4) were between $2.000-21.400 / \mu \mathrm{L}$. Platelet count was between $20.000-988.000 / \mu \mathrm{L}$. $\mathrm{RBC}$ and hemoglobin concentration showed anemia, while $\mathrm{WBC}$ and platelet count are a variation from low, normal to high.

The main symptom in beta thalassemia major is severe anemia due to ineffective erythropoeisis. Increased destruction of the erythrocytes instigates hyperplasia of the RES, erythroid hyperplasia and extramedullary hemopoeisis. Extramedullary hemopoeisis in the spleen initiates splenomegaly. Massive splenomegaly instigates pooling and increases sequestration, resulting in severe anemia, leukopenia, and thrombocytopenia. At this stage, to improve the anemia, splenectomy is advisable. ${ }^{16}$

According to McKenzie, trapped and sequestrated erythrocytes in beta thalassemia major patients are about $9-40 \%$ from the total erythrocyte mass. Neutrophiles undergoes sequestration, setting off slight neutropenia, and trapped thrombocytes amounts to $90 \%$ of the total platelet mass. Splenomegaly makes the anemia, leukopenia and thrombocytopenia worse. 
The relation between spleen enlargement and low erythrocyte, leukocyte and platelet count can be seen in table 5 and figure 4 . In splenomegaly $\mathrm{S}$ (V-VI) cases, mean leukocyte and platelet count were low and became prominent at S (VII - VIII), but after splenectomy the mean leukocyte and platelet count reversed to normal and were higher than normal. We concluded that the larger the spleen, the lower the $\mathrm{Hb}$, $\mathrm{Ht}$, RBC, and platelet count. We assumed that hypersplenism starts at S (V - VI); we could not evaluate hypersplenism through $\mathrm{RBC}$ because beta thalassemia major patients has already had anemia. There has been no earlier report on the relationship between spleen enlargement and hypersplenism in beta thalassemia patients.

We observed in table 4, that there was no leukopenia and thrombocytopenia in the post splenectomy group but there was a tendency towards leukocytosis and thrombocytosis. We also observed in table 5, that there was a rise in the mean $\mathrm{Hb}$ concentration, $\mathrm{Ht}$, and $\mathrm{RBC}$ in this group. The explanation of this phenomenon is that after splenectomy no more pooling and phagocytosis of erythrocytes occurs. The WBC after splenectomy also rises since there was no more pooling of leukocytes, and post splenectomy patients are susceptible to infections. Leukocytosis is also a response to hepatic necrosis. Thrombocytosis as high as one million $/ \mu \mathrm{L}$ can happen during the first months after splenectomy as no more pooling occurs. ${ }^{21}$

Beta thalassemia major has a specific hemoglobin electrophoresis pattern: $\mathrm{HbA}, \mathrm{HbA} 2$, a dense $(10-$ 90\%) $\mathrm{HbF}$ fraction, with no abnormal hemoglobin found. Only 25 (21.5\%) out of 115 subjects participating in this study showed a dense $\mathrm{HbF}$ fraction with a slight $\mathrm{HbA} 2$ fraction. These subjects received repeated blood transfusion for 4 - 20 years. The remaining 90 (78.3\%) subjects showed a normal hemoglobin electrophoresis pattern, and had received repeated blood transfusion for 3 - 21 years. (Fig. 5 and Table 2)

According to Weatherall, regular and repeated blood transfusion will suppress endogenous erythropoeisis, resulting in an inappropriate hemoglobin electrophoresis pattern. Beta thalassemia major patients in this study were found to have low to normal $\mathrm{HbF}$ concentrations, although the blood sample was taken before the next transfusion. We concluded that hemoglobin analysis in patients already receiving blood transfusions cannot be used to confirm the diagnosis of beta thalassemia major. Hemoglobin analysis of the parents could be helpful to support the diagnosis in this situation. Genetic analysis by biomolecular technique is suitable to validate the diagnosis, in such case.

\section{CONCLUSION}

Hematology parameters and hemoglobin electrophoresis from 115 thalassemia major subject attending the Thalassemia Center Department of Paediatrics, Medical School University of Indonesia-Cipto Mangunkusumo General Hospital for routine blood transfusion were examined. The hematology results varied and were not as specific as the classical beta thalassemia major. Hemoglobin values ranged between 4.2-9.6 g/dL, hematocrit between 11-28\%, RBC between 1.54-3.95 million/ $\mu \mathrm{L}$, WBC between $2,000-21,400 / \mu \mathrm{L}$, and platelet count between 20,000$988,00 / \mu \mathrm{L}$. Mean corpuscular values were as follows, MCV 62-88 fL, MCH 19-33 pg, and MCHC 26-39 $\mathrm{g} / \mathrm{dL}$. The condition of the spleen correlated with all hematology parameter, the values tend to decrease with the enlargement of the spleen. All hematology parameters return to normal after splenectomy. We observed in this study that hypersplenism begins when the spleen is as big as $\mathrm{S}$ (V-VI). The hemoglobin electrophoresis did not show the typical beta thalassemia major pattern, only $25(21.7 \%)$ out of $115(100 \%)$ showed a dense $\mathrm{HbF}$ fraction.

A hemoglobin analysis from the parents could be helpful to confirm the diagnosis of beta thalassemia major in subjects who had received blood transfusion. A genetic analysis by bio-molecular technique is suitable to validate the diagnosis, in such a case.

\section{REFERENCES}

1. Lukens JN. The thalassemias and related disorders quantitative disorders of hemoglobinsynthesis. In : Lee GR, Bithell TC, Foerster J, Athens JW, Lukens JN, editors. Wintrobe's clinical hematology. 9th ed. Philadelphia : Lea \& Febiger; 1993.p. 1102 - 45.

2. McKenzie SB. Anemias caused by abnormalities in globin biosynthesis. In: McKenzie SB, editor. Textbook of hematology. 2nd ed. Baltimore : Williams \& Wilkins; 1996.p.164 - 71 .

3. Olivieri NF, Nathan DG, MacMillan JH, Wayne AS, Liu $\mathrm{PP}, \mathrm{McGee}$ A et al. Survival in medically treated patients with homozygous thalassemia. N Eng J Med 1994; 331(9) : 574 - 8 .

4. Weatherall DJ. The thalassemias. In : Beutler E, Lichtman MA, Coller BS, Kipps TJ, editors. William hematology. 5th ed. New York : McGraw Hill Inc.; 1985.p. 581 - 615. 
5. Harrison CR. Hemolytic anemias : intracorpuscular defects : thalassemia. In : Pittiglio DH, Sacher RA, editors. Clinical hematology and fundamentals of hemostasis. 1 st ed. Philadelphia : FA. Davis Company; 1987.p. 117 - 36.

6. Wahidijat I. Penelitian thalassemia di Jakarta (tesis). Jakarta : Universitas Indonesia; 1979.

7. Weatherall DJ, Clegg JB. The $\beta$ thalassaemias. In : Weatherall DJ, Clegg JB, editors. The thalassaemia syndromes. $3 \mathrm{rd}$ ed. Oxford : Blackwell Scientific Publications; 1981.p. 196-7.

9. Anonymous. Cell-dyn 1700 training manual. Abbott Diagnostics.

10. Anonymous. Leaflet hemoglobin electrophoresis procedure. Belmount : Helena laboratories, 1986

11. Santoso W. Hematologic pattern of beta thalassemia heterozygote and beta thalassemia - HbE. Thesis. Department of Clinical Pathology, Medical School, University of Indonesia. Jakarta ; 1991.

12. Wirawan R. Peripheral blood film examination. In : Wirawan R, Silman E, editors. Simple hematology assessment. 2 nd ed. Jakarta ; Balai Penerbit FKUI; 1996. p. 29.

13. Dacie JV, Lewis SM. Quality assurance. In: Dacie JV, Lewis SM, editors. Practical hematology. 8th ed. Hongkong : Churchill Livingstone; 1996 .p. 35 - 47.

14. National Committee for Clinical Laboratory Standards. Performance goal for the internal quality control of multichannel hematology analyzers. National Committee for Clinical Laboratory Standards 1989; 9(9): 633 - 41.
15. Lie-Injo LE. Pathological hemoglobinin Indonesia. Dissertation. Faculty of Medicine University of Indonesia. Jakarta; 1956.

16. Weatherall DJ, Clegg JB. The $\beta$ thalassemias. In : Weatherall DJ, Clegg JB, editors. The thalassaemia syndromes. 3 rd ed. Oxford : Blackwell Scientific Publications; 1981 .p. $148-279$.

17. Weatherall DJ, Clegg JB. The $\beta$ thalassemias. In : Weatherall DJ, Clegg JB, editors. The thalassaemia syndromes. 3 rd ed. Oxford : Blackwell Scientific Publications; 1981.p. 156-7.

18. McKenzie SB. Structure and function of hematopoietic organs and development of blood cells. In : McKenzie SB, editor. Textbook of hematology. 2nd ed. Baltimore : Williams \& Wilkins; 1996.p. 12 - 4, 550.

19. Piomelli S, Loew T. Management of thalassemia major. In : Nagel RL, editor. Hematology/oncology clinics of North America : haemoglobinopathies. Philadelphia : W.B. Saunders Company; 1991.p. 557 - 69.

20. Lewis SM. The spleen. In : Hoffbrand AV, Lewis SM, editors. Postgraduate hematology. 3rd ed. Oxford : Heinemann Professional Publishing Ltd; 1989.p. 16 - 24.

21. McKenzie SB. Nonmalignant granulocyte and monocyte disorders. In : McKenzie SB, editor. Textbook of hematology. 2nd ed. Baltimore : Williams \& Wilkins; 1996 .p. $275-80$.

22. McKenzie SB. Disorders of primary hemostasis. In : McKenzie SB, editor. Textbook of hematology. 2nd ed. Baltimore : Williams \& Wilkins; 1996.p. 551 - 2. 